March $2000 \quad$ - NREL/TP-550-27999

\title{
Progress on Linking Gender and Sustainable Energy
}

\author{
Barbara C. Farhar
}

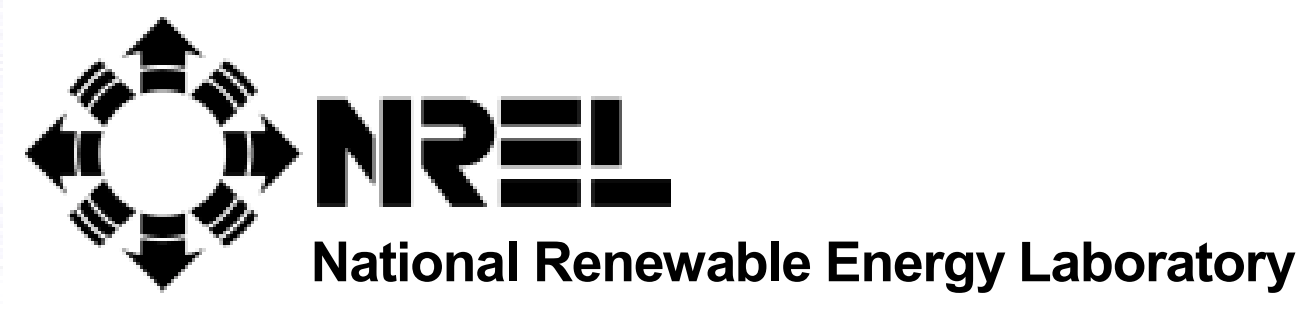

1617 Cole Boulevard

Golden, Colorado 80401-3393

NREL is a U.S. Department of Energy Laboratory

Operated by Midwest Research Institute $\bullet$ Battelle $\bullet$ Bechtel

Contract No. DE-AC36-99-G010337 


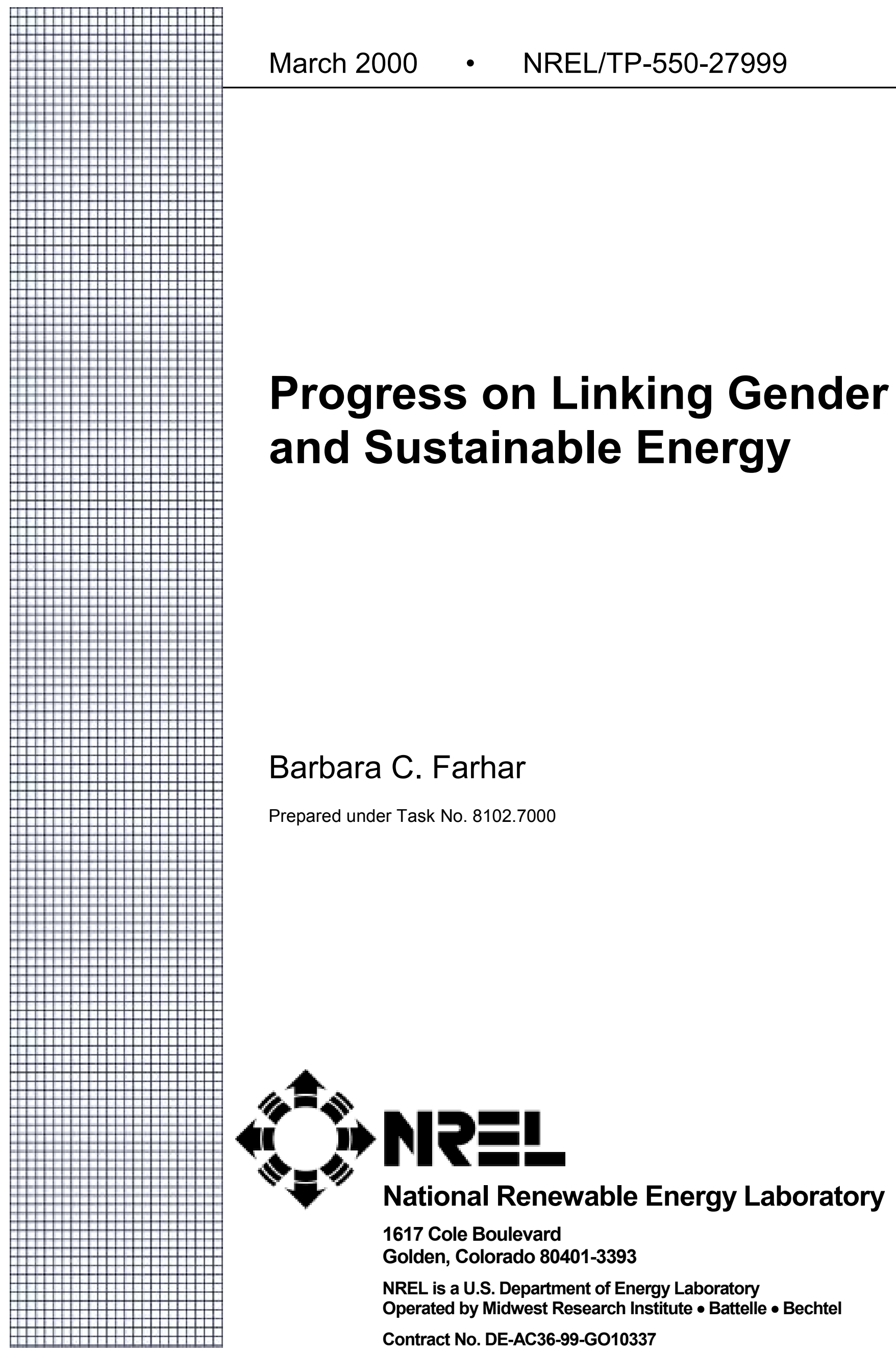




\section{NOTICE}

This manuscript has been authored by Midwest Research Institute under contract No. DE-AC3699G010337 with the U.S. Department of Energy. The United States Government retains and the publisher, by accepting the article for publication, acknowledges that the United States Government retains a non-exclusive, paid-up, irrevocable, world-wide license to publish or reproduce the published form of this manuscript, or allow others to do so, for United States Government purposes.

This report was prepared as an account of work sponsored by an agency of the United States government. Neither the United States government nor any agency thereof, nor any of their employees, makes any warranty, express or implied, or assumes any legal liability or responsibility for the accuracy, completeness, or usefulness of any information, apparatus, product, or process disclosed, or represents that its use would not infringe privately owned rights. Reference herein to any specific commercial product, process, or service by trade name, trademark, manufacturer, or otherwise does not necessarily constitute or imply its endorsement, recommendation, or favoring by the United States government or any agency thereof. The views and opinions of authors expressed herein do not necessarily state or reflect those of the United States government or any agency thereof.

Available electronically at http://www.doe.gov/bridge

Available for a processing fee to U.S. Department of Energy and its contractors, in paper, from:

U.S. Department of Energy

Office of Scientific and Technical Information

P.O. Box 62

Oak Ridge, TN 37831-0062

phone: 865.576.8401

fax: 865.576.5728

email: reports@adonis.osti.gov

Available for sale to the public, in paper, from:

U.S. Department of Commerce

National Technical Information Service

5285 Port Royal Road

Springfield, VA 22161

phone: 800.553 .6847

fax: 703.605.6900

email: orders@ntis.fedworld.gov

online ordering: http://www.ntis.gov/ordering.htm 


\title{
PROGRESS ON LINKING GENDER AND SUSTAINABLE ENERGY
}

\author{
BARBARA C. FARHAR, Ph.D. \\ National Renewable Energy Laboratory, 1617 Cole Boulevard, Golden, CO 80401 USA
}

\begin{abstract}
The field of gender and energy has been identified as critical in global sustainable energy development and is increasingly important to decision makers. The theme of women and energy was of significance at the 1998 World Renewable Energy Congress in Florence, Italy. This paper traces further developments in this field by summarizing selected programmatic initiatives, meetings, and publications over the past 18 months.
\end{abstract}

\section{KEYWORDS}

Gender roles; renewable energy; energy policy; analysis; marketing; sustainable development.

\section{INTRODUCTION AND BACKGROUND}

Global energy decision making has often emphasized large-scale, high-technology energy to provide electricity and gas to the elite few able to take advantage of them. Often, international development programs have not adequately addressed the energy needs of billions of the world's people, especially the world's women. Yet the energy problems in developing countries largely affect women. Many women gather wood for cooking, spend up to five hours a day in food preparation, and breathe the particulates that wood, charcoal, and kerosene burning emit. Women haul water where no pumping is available. In fact, women spend as much as 12 hours a day on subsistence activities; time that could be spent in other ways, such as increased education and income-producing activity — and even recreation — if sufficient energy resources were available to them (Cecelski, 1992; Farhar, 1998b).

Gender and energy issues should receive considerable attention in the renewable energy community. The theme of women and energy was a focus of the World Renewable Energy Congress-V (WREC-V) in Florence, Italy, in September 1998. This Congress had more activities on gender and energy than any major energy meeting up to that time, including six presentations related to gender and energy in technical sessions, three plenary talks, one workshop, and one award. Several programmes were discussed, including the Grameen Shakti in Bangladesh, the Adesol Project in Honduras, Indian Renewable Energy Development Agency projects, activities of the AllIndia Women's Conference, and ENERGIA, the international network on women and energy (Farhar, 1998a). 
At WREC-V, the recommendation was made that a global assessment for gender and energy, or GAGE, project should be undertaken to assess the state of knowledge on gender and energy, in which researchers and practitioners would come together to identify what is known to help nations and the international community improve the focus of efforts in this field. Better understanding is needed about how renewable energy solutions affect men and women differently so that organizational responsibilities and resources can be accurately targeted. It was also stated that the opportunity now exists to mainstream gender in sustainable energy development (SED) as a credible field of research and practice.

The purpose of this paper is to provide an update on gender and SED activities since the 1998 WREC-V meeting. Significant advances are being made to improve knowledge and practice in this field. Several events that have occurred during the past 18 months are mentioned: three gender and energy programmatic initiatives and several key meetings held or proposed. Gender and energy issues are briefly summarized within the context of international concerns as represented by the Beijing +5 Conference to be held in New York in June 2000 on the fifth anniversary of the U.N. Conference on the Status of Women held in Beijing, China.

\section{PROGRAMMATIC INITIATIVES}

- United Nations Development Programme (UNDP), Women in Energy Project. Located in UNDP's Energy and Atmosphere Programme, this project's goal is to improve conditions for women in developing countries by supporting the initiation of sustainable energy pilot activities designed to promote income-generating opportunities for women. The geographical focus of the project is Africa, where large numbers of people lack modern energy services and where there is great potential for utilizing renewable energy resources. The objectives are to (1) provide an analytical framework for determining the elements of successful SED projects that benefit women, (2) network with interested parties for information-sharing, training, and advocacy activities, (3) initiate sustainable energy pilot activities that are designed to generate income-earning opportunities for women, and (4) monitor and evaluate the project's impacts (Karlsson, 1999a).

- Energy Sector Management Assistance Programme Gender Facility Initiative (ESMAP/GF), World Bank. The ESMAP programme focuses on the role of energy in economic development with the objective of contributing to poverty alleviation and economic progress, improving living conditions, and preserving the environment. The programme provides policy advice and technical assistance to governments. The Gender Facility's objective is to build a body of good practice on gender in energy by mainstreaming gender issues into ESMAP assistance, increase knowledge and practice of gender mainstreaming through collection and dissemination of lessons learned, and to increase the inclusion of energy issues in the gender and development discourse (Fong, 1999). ESMAP is working with the ENERGIA Network and the UNDP on ways to share information on best practices regarding energy and women.

- National Renewable Energy Laboratory (NREL). The laboratory has initiated several gender and energy activities, including a bibliography on gender and energy, and has sponsored a Symposium on Women and Energy at the World Renewable Energy Congress-IV in Denver, Colorado, USA, in 1996. NREL also coorganized, with the Commonwealth Council on Science and Technology, women's sessions at WREC-V in Florence, Italy, a Workshop on Gender and Energy, and a plenary speaker on gender at Village Power '98. NREL has commissioned three seminal papers in the field of gender and SED. These papers are under preparation for publication (Cecelski, 2000), solar-based rural electrification in Latin America (Smith, 2000), and gender challenges in scaling up rural electrification (Cecelski, 2000). 


\section{KEY MEETINGS}

A number of significant meetings pertinent to gender and SED have been held since the WREC-V in 1998.

- Village Power '98, Washington, DC, October 1998. A plenary address focused on gender and poverty challenges in scaling up rural electricity access. A workshop focusing on linkages between sustainable energy and gender was held in concert with the meeting. Participants included analysts and development experts from several countries. They reached consensus that access to sustainable energy in rural areas is particularly difficult for women; that participation of local people, including women, is essential for successful SED; that international financing agencies should integrate energy into their gender policies; that electricity access can be increased by matching resources to women's energy needs; and that financing should be actively extended to women to acquire sustainable energy systems.

- Regional Workshop for Southern Africa, United Nations Development Programme, Energy and Women Project, Pretoria, South Africa, June 21-22, 1999. The first of three workshops planned, this workshop resulted in suggestions for UNDP on how it can best provide support for national action relative to women in energy in Angola, Bostwana, Lesotho, Mozambique, Namibia, South Africa, Swaziland, Zambia, and Zimbabwe. Significant concerns identified at the workshop include hardships on women because of a lack of energy services and gender insensitive energy policies; insufficient evaluation of unsuccessful energy projects; a shortage of women's participation in energy projects; a lack of information, education, and training for women; and inadequate financing arrangements. Major recommendations from the workshop included the need for income generation for poverty alleviation; advocacy to eliminate legal barriers to women's access to credit because of requirements for male consent or for collateral that differs according to gender; community initiatives; networking and information sharing; critical analysis of energy projects; and training programs (Karlsson, 1999b). A second workshop was held in Nairobi in March 2000.

- ENERGIA Workshop on Improving Women's Access to Energy: Policy, Projects or the Market?, Enschede, the Netherlands, November 1999. The workshop included participants from Australia, Denmark, Germany, Guatemala, India, Kenya, Lao People's Democratic Republic, Senegal, Sweden, the United Kingdom, and the United States. The workshop's purpose was to focus on the cutting-edge questions in the field of gender and energy with sessions on mainstreaming; employment through energy; Asian and African perspectives on policy, projects, or the market as appropriate models; network building and regionalisation; and advocacy. Among several important papers presented were Clancy (1999), Annecke (1999), Büttner and Winkler (1999), and Prathoumvanh (1999).

- Meeting of the ENERGIA Advisory Board, Enschede, the Netherlands, November 1999. The workshop was followed by an ENERGIA Board meeting (http:/www.energia.com) at which the management of the ENERGIA second phase and a logical framework analysis were presented. ENERGIA will now have a fulltime director: Sheila Oparaocha. The project will result in publishing several more issues of the ENERGIA News, continuing and improving an ENERGIA resource centre, continuing efforts at regionalisation, and ongoing research and development efforts.

- The World Bank, Washington, DC, January 2000. A brainstorming meeting on Asia Alternative Energy Policy and Project Development Support: Emphasis on Poverty Alleviation and Women, was held at the Asia Alternative Energy Unit of the World Bank in Washington, DC, in January 2000. Key needs identified included data needs and analysis; wood energy, cooking, and health; women's specific electricity needs, such as water pumping, agricultural processing, security, work productivity, and health; and equal access to credit, extension, and training (Cecelski, 2000). 
- A workshop on Women and Sustainable Energy Development has been proposed for the Village Power 2000 Conference to be held in October in Washington, DC. A final decision by conference organizers is pending.

\section{INTERNATIONAL CONTEXT ON THE STATUS OF WOMEN}

Gender and energy issues require both technological and policy solutions. As Clancy (1999) has pointed out, understanding is growing within international fora about the linkages among women, energy, and sustainable development. Agenda 21, from the 1992 U.N. Conference on Environment and Development in Rio de Janeiro, Brazil, called for governments to actively implement programs for environmentally sound technologies, in consultation with women, for clean water, an efficient fuel supply, and adequate sanitation.

The sustainable energy community should develop and offer technologies that will address women's critical needs as women define them. The 1995 U.N. Conference on the Status of Women held in Beijing, China, resulted in identification of 12 critical areas in which progress must be made to improve the status of women (see Appendix A). Science and technology, including the field of sustainable energy, can assist in the advancement of women in these critical areas in direct and indirect ways.

The appropriate application of sustainable energy technologies has great potential for empowering women. In programs for developing countries, women's issues receiving the most attention include improvement of health, reducing drudgery, reducing poverty through income opportunities, improving women's access to credit, improving women's rights to own and control land, and patenting women's indigenous knowledge so they can benefit from its use. These issues have been defined as critical by women themselves, as shown in Appendix A. Because sustainable energy technologies can provide energy that applies to many of the critical issues defined by women, the sustainable energy community should begin to explore the complex linkages between energy inputs and solutions to these problems.

Energy is a basic input that can support many women's activities around the world. For example, off-grid energy applications would enable power for cellular phones and computers - wireless communications that leapfrog over the more conventional wired infrastructure in the developed world. These communications technologies can help bridge the "digital divide" that separates those with and without access to the Internet. With wireless communications, producers in rural communities can market goods directly, can find out prices in the cities in order to know when to bring goods to market, and can establish local communications enterprises. Women can have the opportunity to receive and send information, potentially transforming their self-perception as persons capable of initiating messages important to others. Although barriers to such scenarios are significant, solutions must be found. Science and technology are here to stay.

For positive applications of energy technology to occur, women need education and training in science and technology. They also need to assist in defining how science and technology knowledge will be applied in their own communities for the well-being of all. And, women need sustainable energy sources.

The sustainable energy community can work to actively involve women in the design of technologies and in their application. The advice and indigenous knowledge of women about cooking, water, foods, medicines, and their roles in energy supply and use can be actively exchanged to improve the effectiveness of sustainable energy technologies and to support sound economic development that betters the quality of life for families, communities, and women themselves. 


\section{REFERENCES}

Annecke, W. J. (1999). "From the Kitchen to the Boardroom: Reflections on Power Relations in Gender and Energy Practice and Policy.” Energy and Development Research Centre, University of Cape Town, South Africa: paper presented at the ENERGIA Workshop on Improving Women's Access to Energy, University of Twente, Enschede, the Netherlands. November.

Büttner, L. and K. Winkler. (1999). "Gender and Sustainable Energy in Central America: Increasing Capacity through a Regional Network. Winrock International and Fundación Solar: paper presented at the ENERGIA Workshop on Improving Women's Access to Energy, University of Twente, Enschede, the Netherlands, November.

Cecelski, E. (2000). Forthcoming. The Role of Women in Sustainable Energy Development. National Renewable Energy Laboratory, Golden, CO.

Cecelski, E. 2000. Forthcoming. Gender and Poverty Challenges in Scaling Up Rural Electricity Access. National Renewable Energy Laboratory, Golden, CO.

Cecelski, E. (2000). "Enabling Equitable Access to Rural Electrification: Current Thinking and Major Activities in Energy, Poverty, and Gender." Briefing paper prepared for a Brainstorming Meeting on Asia Alternative Energy Policy and Project Development Support: Emphasis on Poverty Alleviation and Women, Asia Alternative Energy Unit, The World Bank, Washington, DC. January 26-27.

Cecelski, E. (1992). Women, Energy and Environment: New Directions for Policy Research. Working Paper Series, Gender Science and Development Programme - 2, 46 pp. International Federation of Institutes for Advanced Study, Toronto.

Clancy, J. (1999). "Policies, Projects, and the Market, Empowering Women: Some Initial Reactions to Developments in the Energy Sector." University of Twente, Enschede, the Netherlands: paper presented at the ENERGIA Workshop on Improving Women's Access to Energy, University of Twente, Enschede, the Netherlands. November.

Energy Sector Management Assistance Programme. (n.d.) "Promoting Energy Solutions for Economic Development." The World Bank, Washington, DC.

Farhar, B. C. (1998a). Gender and Renewable Energy: Policy, Analysis, and Market Implications. Renewable Energy, 15, 230-239.

Farhar, B. C. (1998b). Women's Activities. WREN News, Winter, pp. 1-2.

Fong, M. (1999). ESMAP Gender Facility. Draft. The World Bank, Washington, DC.

Karlsson, G. (1999a). How is Gender Relevant to Sustainable Energy Policies? Draft. United Nations Development Programme, New York.

Karlsson, G. (1999b). Energy and Women Project. Report on Regional Workshop for Southern Africa, Pretoria, South Africa, June 21-22, 1999. Draft. United Nations Development Programme, New York. September 18.

Prathoumvanh, B. (1999). "Overview of Gender and Wood Energy in the Lao PDR." Gender Resource Information and Development Center, Lao Women's Union, Vientiane Lao PDR: paper presented the ENERGIA Workshop on Improving Women's Access to Energy, University of Twente, Enschede, the Netherlands. November.

Smith, J. A. (2000). Forthcoming. Solar-Based Rural Electrification and Microenterprise Development in Latin America: A Gender Analysis. National Renewable Energy Laboratory, Golden, CO. 
APPENDIX A. THE 12 CRITICAL AREAS DEFINED IN 1995 BY THE U.N. CONFERENCE ON WOMEN IN BEIJING

Economy

Education and training

Environment

Health

Media

Poverty

Armed conflict

Decision making

"The Girl-Child"

Human rights

Institutional

mechanisms

Violence
Discrimination by gender exists for women in hiring, remuneration, promotion, working conditions, access to productive resources, and sharing of family responsibilities.

Discrimination by gender exists for women in education and training, especially vocational training, training in science and technology, and continuing education; women have a higher illiteracy rate than men.

The deterioration of the environment and depletion of natural resources negatively affects the health and well-being of girls and women differently from boys and men.

Discrimination by gender exists in access to quality health care and health information; unequal relations exist in matters of sexual relations and reproduction.

In most countries, the media project a negative and degrading image of women (i.e., often violent and pornographic); women rarely reach media power positions.

Poverty disproportionately affects women and children; women have fewer economic opportunities than men; women lack autonomy; women lack access to credit; women lack control of land; laws and practices discriminate against women economically; social roles are rigid and inflexible; women are caught in subsistence level activities (i.e., gathering fuel, hauling water) with little or no time to develop economic activity.

Participation in armed conflict varies by gender; women suffer from rape, widowhood, and loss of children as a consequence of war; women lack power and authority in decisions leading to armed conflict.

Women remain under-represented in decision-making positions in most spheres of economic, political, religious, athletic, arts, media, law, culture, and scientific activities.

Girls are more vulnerable than boys to discriminatory practices, such as female genital mutilation, son preference, early marriage, lack of educational and training opportunities, kidnapping and sexual exploitation, practices related to health and food allocation, child labor exploitation, negative cultural attitudes and practices, and violence (both domestic and societal).

The international norms on human rights are not being implemented in many parts of the world, with discriminatory practices particularly affecting the human rights of girls and women.

Mechanisms for the advancement of women are ineffective in most countries because of a lack of adequate resources and clear mandates, lack political leadership, and gender policy analysis.

Women are more subject than men to physical, sexual, and psychological abuse at home, in communities, and in the workplace; they suffer from systematic violence during war. 


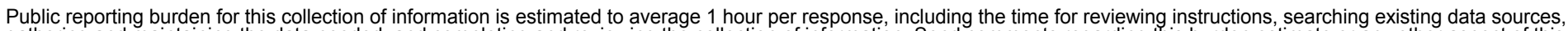

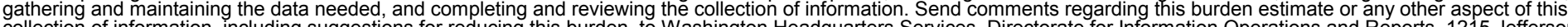
Davis Highway, Suite 1204, Arlington, VA 22202-4302, and to the Office of Management and Budget, Paperwork Reduction Project (0704-0188), Washington, DC 20503.
1. AGENCY USE ONLY (Leave blank)
2. REPORT DATE
3. REPORT TYPE AND DATES COVERED
March 2000
Technical Report

4. TITLE AND SUBTITLE

5. FUNDING NUMBERS

Progress on Linking Gender and Sustainable Energy

8102.7000

6. $\operatorname{AUTHOR}(\mathrm{S})$

Barbara C. Farhar, PhD.

7. PERFORMING ORGANIZATION NAME(S) AND ADDRESS(ES)

World Renewable Energy Network

147 Hilmanton, Lower Earley

Reading RG6 4HN, United Kingdom

9. SPONSORING/MONITORING AGENCY NAME(S) AND ADDRESS(ES)

National Renewable Energy Laboratory

1617 Cole Blvd.

Golden, CO 80401-3393
8. PERFORMING ORGANIZATION REPORT NUMBER

11. SUPPLEMENTARY NOTES

NREL Technical Monitor: Jill Anderson

12a. DISTRIBUTION/AVAILABILITY STATEMENT

National Technical Information Service

U.S. Department of Commerce

5285 Port Royal Road

Springfield, VA 22161
10. SPONSORING/MONITORING AGENCY REPORT NUMBER

TP-550-27999

13. ABSTRACT (Maximum 200 words)

The field of gender and energy has been identified as critical in global sustainable energy development and is increasingly important to decision makers. The theme of women and energy was of significance at the 1998 World Renewable Energy Congress in Florence, Italy. This paper traces further developments in this field by summarizing selected programmatic initiatives, meetings, and publications over the past 18 months.

14. SUBJECT TERMS

15. NUMBER OF PAGES

Gender roles, renewable energy, energy policy, analysis, marketing, sustainable development

16. PRICE CODE

17. SECURITY CLASSIFICATION OF REPORT Unclassified

18. SECURITY CLASSIFICATION OF THIS PAGE Unclassified
19. SECURITY CLASSIFICATION OF ABSTRACT Unclassified
20. LIMITATION OF ABSTRACT

UL 